\title{
Recent trends in alumina and aluminium production technology
}

\author{
H MAHADEVAN ${ }^{\dagger}$ and T R RAMACHANDRAN* \\ Jawaharlal Nehru Aluminium Research Development and Design Centre, Wadi, Nagpur \\ 440023, India \\ ${ }^{+}$Present address: Larsen and Toubro, Powai Works, Mumbai 400072, India
}

\begin{abstract}
For well over a century the Bayer process for the production of alumina from bauxite and the Hall-Heroult process involving the electrolysis of alumina dissolved in cryolite to produce aluminium have been commercially exploited. However, significant advances based on intense research and development activities in the last five decades have led to considerable improvements in operating parameters and productivity, efficient disposal and utilization of wastes. This review presents the developments that have taken place in technology, equipment and treatment of wastes in both the alumina and aluminium production processes.

Technology and equipment developments in the field of alumina are concerned with usage of different qualities of bauxite, improvement in extraction efficiency of alumina from bauxite, obtaining better yield during precipitation, enhancing scale of operation and minimizing soda losses in the process. Improvements in electrolysis involve utilization of modified electrolytic baths, controlled feeding of alumina, better design of cell based on mathematical modelling of magnetic field and heat distribution and optimization of the performance of electrodes on the basis of good understanding of physical, mechanical and electrical properties. Information on the present situation in the Indian plants is also presented. Proper treatment and disposal of wastes generated in alumina and aluminium production are of great importance as they contain significant amounts of sodium hydroxide, fluorides, sulphur dioxide, oxides of carbon and cyanide. Some attempts made to utilize the waste material are briefly summarized.
\end{abstract}

Keywords. Alumina and aluminium production; developments in technology and equipments; waste disposal and utilization.

\section{Introduction}

Aluminium is the most widely used nonferrous metal. The production of the metal has increased by nearly four times in the last three decades; this is illustrated in figure 1 for bauxite, alumina and aluminium; it can be seen that the present annual production figures for the ore, oxide and metal are 103, 42 and 19 million tonnes respectively (Plunkert 1993).

The Bayer process for the production of alumina (which accounts for about $95 \%$ of total output) involves preferential dissolution (by digestion) of alumina from the ore and precipitating the hydrate under conditions exactly reverse to those of digestion. Many impurities also get dissolved during digestion and are to be removed to produce a product of desired quality. The unit operations involved are crushing, grinding, settling, washing and filtration, whereas the unit processes are desilication, digestion, precipitation and calcination. A typical flowsheet of the process is shown in figure 2. The basic Bayer process has almost been unaltered from its invention and would be the primary route for producing smelter and chemical grades of alumina in the years to come.

The Hall-Heroult process for the production of aluminium based on the electrolysis of alumina dissolved in cryolite, using carbon anodes and cathodes, was introduced in 1886 and is still the most important process for the production of the metal. Continuous research and development activities for nearly five decades have led to substantial

*Author for correspondence 


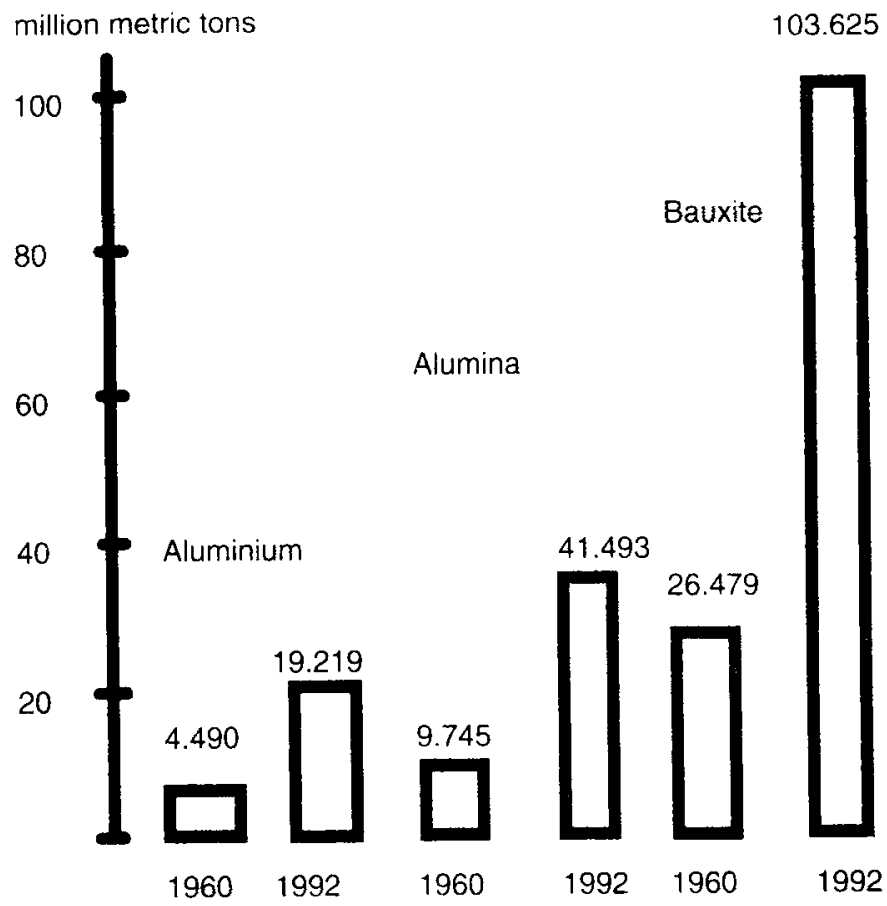

Figure 1. World bauxite, alumina and aluminium production in the years 1960 and 1992 .

improvements in the electrolysis parameters and reduction in material consumption. These include modification of the electrolyte by the addition of a variety of salts, controlled feeding of alumina to the electrolyte, maintaining proper heat and magnetic field conditions, understanding the influence of the properties of raw materials on manufacture and performance of electrodes and methods for proper and efficient disposal of waste products. Some of these aspects are reviewed in this paper.

\section{Alumina production}

The conditions for digestion of bauxite are influenced by mineralogical compositionpredominantly gibbsite containing ores can be digested at relatively low temperatures, $110^{\circ} \mathrm{C}-150^{\circ} \mathrm{C}$ while diaspore and boehmitic grades may require temperatures as high as $260^{\circ} \mathrm{C}-300^{\circ} \mathrm{C}$. The consumption of sodium hydroxide in the process is influenced by the amount of reactive silica in the ore and the care exercised in recovering caustic at various stages of the Bayer process.

Improvements in Bayer process have been mainly through the innovations in technology and the development of equipment. The following are the advantages resulting from these improvements:

- bauxite having varying chemical and mineralogical composition can be processed easily.

- liquor productivity at digestion (amount of dissolved alumina) and precipitation (amount of precipitated alumina) has increased, enabling reduction of liquor specific volume, and thereby contributing to increased capacities. 


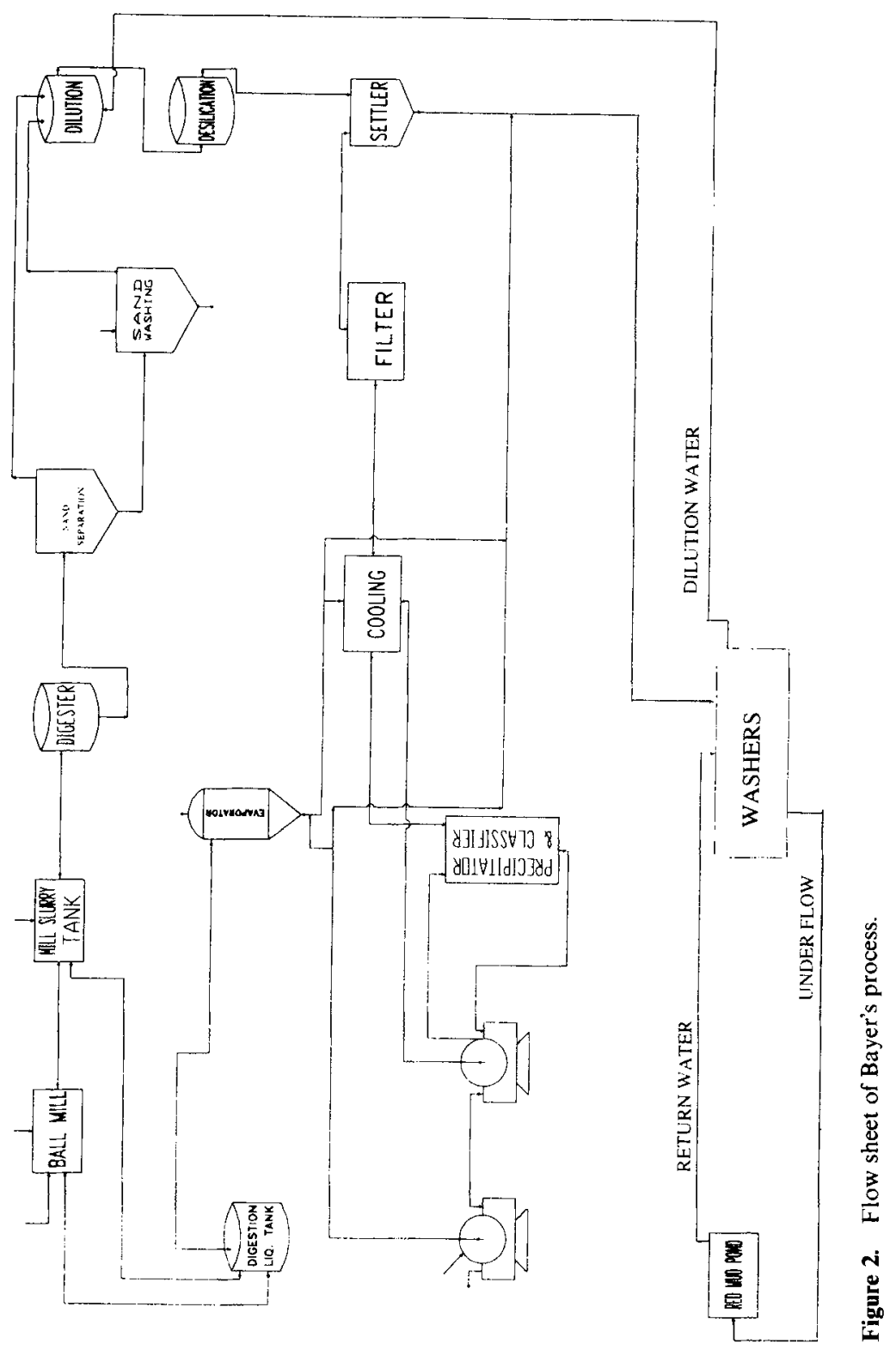


Table 1. Equipment and technological developments in Bayer process.

\begin{tabular}{ll}
\hline Technology & Equipments \\
\hline - Atmospheric digestion & - Rod mill* \\
- Low pressure digestion & - Pug mill* \\
- High pressure digestion & - Deep thickener* \\
- Sweetening* & - High rate thickener* \\
- Double stream digestion* & - Dry stacking** \\
- Parallel stream digestion* & - Solar drying* \\
- Lime addition at & - High capacity precipitation** \\
- digestion & unit $>4000 \mathrm{~m}^{3}$ \\
- security filtration & \\
- liquor causticization & \\
- complex causticization & \\
- Synthetic flocculants & - Fluidized bed calciners \\
- Alusuisse precipitation & \\
technology* & - Gas suspension calciners \\
\hline
\end{tabular}

*Not in use in Indian plants; **in use in one plant

- the product quality has improved considerably enabling production of superpurity metal and also special aluminas.

- environmental problems have been reduced considerably and the solid/liquor wastes generated are disposed off safely.

Details of various technological and equipment developments made in this field in the last five decades are given in table 1 (Feik and Cordes 1971; Dixon and Schunk 1993; Doucet 1993).

As mentioned earlier, the main emphasis is to reduce the consumption parameters and improve productivity. The main factors affecting the competitiveness of the production process are plant size and liquor productivity.

The first alumina plant set up in 1894 had a capacity of 4 tonnes per year (tpy). Since then the plant capacity has been steadily increasing, attaining the level of $1-1.5$ million tpy in 1980. The present day plant capacity is invariably around 1-2 million tpy. The distribution of world alumina production capacity by plant size is shown in figure 3 (King 1993). It can be seen from the figure that while in $1970,80 \%$ of the world alumina production was confined to plants with less than 1 million tpy capacity, at present more than $62 \%$ of the world alumina production is from plants above 1 million tpy and $20 \%$ above 2 million tpy. The component of capital investment in the cost of alumina production is significantly decreased by increasing the plant size -- this implies that the giant plants would dictate the alumina market price. Equipment efficiency, maintenance, the cost of instrumentation and process control and manpower are all highly dependent on the plant size. The comparative production capacities of the largest alumina refineries of the world (which together account for about $62 \%$ of the total world capacity) are given in figure 4 (King 1993).

Liquor productivity influences significantly the alumina production cost by increasing the process efficiency. The American precipitation technology produces sandy alumina (better quality) with low liquor productivity (around $45-55 \mathrm{~kg} / \mathrm{m}^{3} \mathrm{Al}_{2} \mathrm{O}_{3}$ ), 


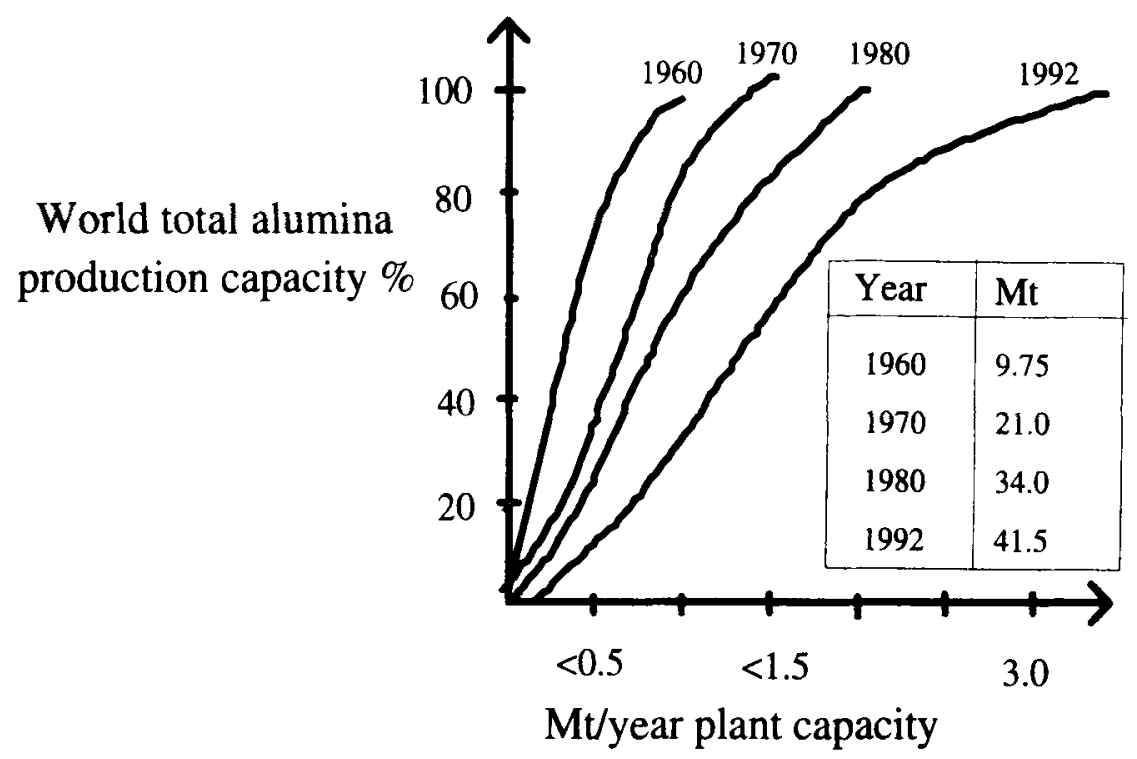

Figure 3. Distribution of world alumina production capacity by plant size.

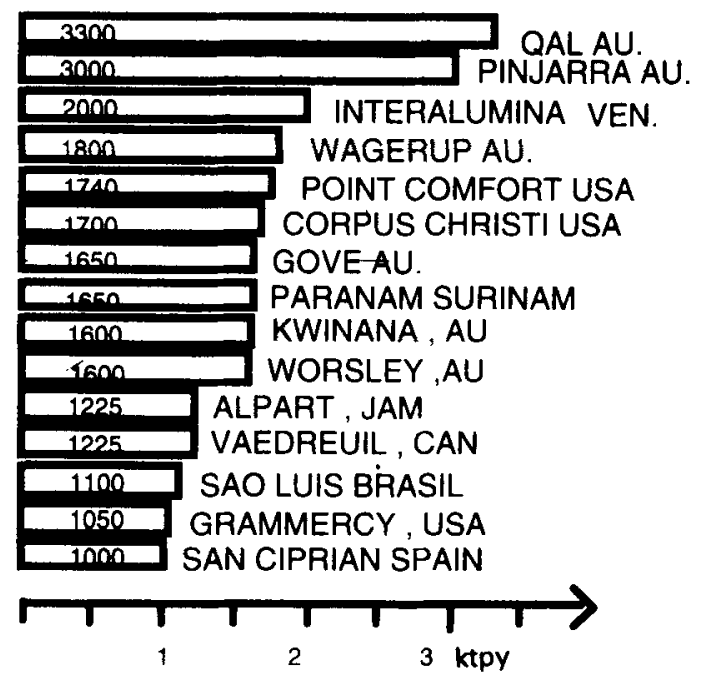

AU:AUSTRALIA

Alumina plant capacity

USA:UNITED STATES OF AMERICA

CAN:CANADA

JAM:JAMAICA

VEN:VENEZUELA

Figure 4. The largest alumina refineries of the world (62\% of the total world capacity).

while the European precipitation technology yields floury alumina (more of fine particles) with medium liquor productivity (around $65-70 \mathrm{~kg} / \mathrm{m}^{3} \mathrm{Al}_{2} \mathrm{O}_{3}$ ). The basic difference in the two technologies is in the precipitation conditions (temperature, time and soda concentration). The use of sandy alumina is favoured from the point of view of 


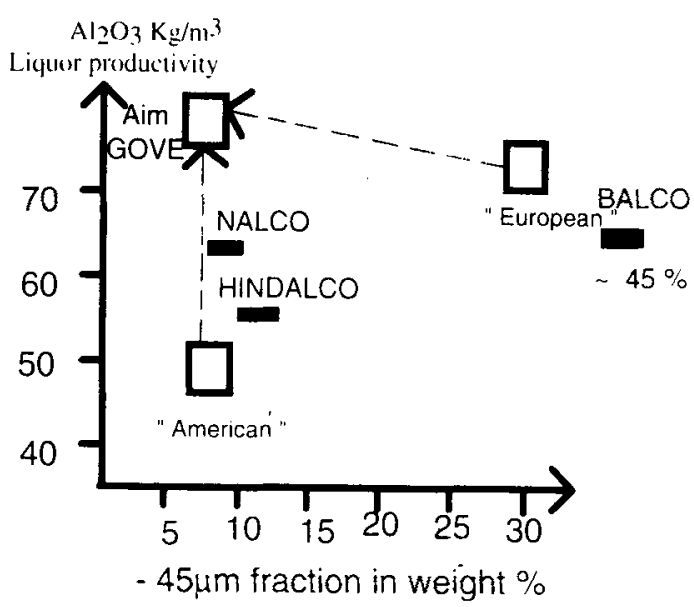

Figure 5. Liquor productivity and product size--present status and future trends.

minimizing fluorine emissions and facilitating process control (Newchurch and Moretto 1990). The 'Alusuisse' precipitation technology offers the advantages of product coarseness $(4-5 \%,-45 \mu \mathrm{m}$ fraction) and high liquor productivity (80$90 \mathrm{~kg} / \mathrm{m}^{3} \mathrm{Al}_{2} \mathrm{O}_{3}$ ). Using this technology, the Venezuelan alumina plants have increased the liquor productivity up to $90 \mathrm{~kg} / \mathrm{m}^{3}$, with plans to reach $100 \mathrm{~kg} / \mathrm{m}^{3}$. The material and energy savings achieved due to the above technological innovations, equipment developments and plant size are shown in tables 2 and 3 , respectively. Major factors contributing to reduction in raw material consumption are the following:

- Exploration and mining of new and improved gibbsitic bauxite together with significant improvement in digestion technology, thereby resulting in lower bauxite and caustic consumption.

- Improvement in mud separation, leading to lower soluble soda losses.

- Lime addition to the Bayer's process resulting in reduction of caustic losses by substitution and also improvement in the product quality.

- Improvement in liquor productivity at precipitation contributing to reduction of specific raw material consumption by as much as $15-20 \%$. This has been made possible by efficient alumina digestion, addition of optimum amount of synthetic flocculants to reduce the content of organics in the system and reducing evaporation capacities by practising less dilution.

The ideal energy consumption for alumina production in $7.88 \mathrm{GJ} / \mathrm{t}$ out of which calcination alone accounts for $3 \cdot 1 \mathrm{GJ} / \mathrm{t}$ (Bielfeldt and Winkhaus 1981). There has been a progressive reduction in energy consumption from $18 \mathrm{GJ} / \mathrm{t}$ alumina to $11-11.5 \mathrm{GJ} / \mathrm{t}$ (Lang et al 1981) with the introduction of energy intensive operations such as tube digestion, improved flashing systems, flash calciners, improved control systems and thyristor drives, efficient transportation of solids and fluids.

The efficient tackling of the solid waste storage problem had helped in land conservation thereby relieving the pressure of availability of space for plant (capacity) expansion. Because of the dry stacking of mud in impoundments, the land requirement has been reduced to less than $30 \%$ of the original requirement with eco-friendly measures. 
Table 2. Material saving in the Bayer process.

\begin{tabular}{|c|c|c|}
\hline Materials & Reason & Typical reduction \\
\hline Bauxite & $\begin{array}{l}\text { Reduction mainly due to } \\
\text { improved bauxite quality } \\
\text { (Chemical and mineralogical } \\
\text { composition) }\end{array}$ & $1-1.3 \mathrm{mt} / \mathrm{t}$ alumina \\
\hline \multirow[t]{6}{*}{ Caustic soda } & $\begin{array}{l}\text { Low reactive silica (would } \\
\text { contribute to low bound soda } \\
\text { losses) }\end{array}$ & $25-45 \mathrm{~kg} \mathrm{NaOH} / \mathrm{t}$ alumina \\
\hline & $\begin{array}{l}\text { Digestion conditions (would } \\
\text { contribute to low bound soda } \\
\text { losses) }\end{array}$ & $15-20 \mathrm{~kg} \mathrm{NaOH} / \mathrm{t}$ alumina \\
\hline & $\begin{array}{l}\text { Lower soluble soda losses } \\
\text { because of improved mud } \\
\text { separation and handling }\end{array}$ & $10-15 \mathrm{~kg} \mathrm{NaOH} / \mathrm{t}$ alumina \\
\hline & $\begin{array}{l}\text { Lime substitution (mud and liquor } \\
\text { causticization) }\end{array}$ & $15-40 \mathrm{~kg} \mathrm{NaOH} / \mathrm{t}$ alumina \\
\hline & $\begin{array}{l}\text { Improved recovery from mud } \\
\text { disposal }\end{array}$ & $2-6 \mathrm{~kg} \mathrm{NaOH} / \mathrm{t}$ alumina \\
\hline & $\begin{array}{l}\text { Improved liquor productivity at } \\
\text { digestion by sweetening and at } \\
\text { precipitation (Alusuisse } \\
\text { technology) }\end{array}$ & $\begin{array}{l}\text { Reduces overall } \\
\text { consumption by as much } \\
\text { as } 20-25 \%\end{array}$ \\
\hline
\end{tabular}

Table 3. Energy savings in the Bayer plant.

\begin{tabular}{|c|c|c|}
\hline Form of energy & Reason & Possible reduction \\
\hline \multirow[t]{3}{*}{ Steam } & $\begin{array}{l}\text { Digestion condition (Tube } \\
\text { digestion) }\end{array}$ & $\begin{array}{l}\text { Reduces steam } \\
\text { requirement by about } 30 \%\end{array}$ \\
\hline & $\begin{array}{l}\text { Liquor concentration (low liquor } \\
\text { concentration leads to less } \\
\text { evaporation) }\end{array}$ & $\begin{array}{l}\text { Reduces steam } \\
\text { requirement by about } \\
10-15 \%\end{array}$ \\
\hline & $\begin{array}{l}\text { Flashing efficiency (increased } \\
\text { reutilization of steam) }\end{array}$ & $\begin{array}{l}\text { Reduces overall steam } \\
\text { consumption by about } \\
8-10 \%\end{array}$ \\
\hline \multirow[t]{3}{*}{$\begin{array}{l}\text { Fuel oil for } \\
\text { calcination of } \\
\text { hydrate }\end{array}$} & $\begin{array}{l}\text { Modified kiln conditions } \\
\text { (retrofitting rotary kilns) }\end{array}$ & $\begin{array}{l}\text { Reduces oil consumption } \\
\text { by } 20-25 \%\end{array}$ \\
\hline & $\begin{array}{l}\text { Replacement of rotary kilns with } \\
\text { fluidized bed/gas suspension } \\
\text { calciners }\end{array}$ & $\begin{array}{l}\text { Reduces oil consumption } \\
\text { by } 35-40 \%\end{array}$ \\
\hline & $\begin{array}{l}\text { Low calcination (low alpha } \\
\text { content in alumina) }\end{array}$ & $\begin{array}{l}\text { Reduces oil consumption } \\
\text { by } 5-10 \%\end{array}$ \\
\hline Electric power & $\begin{array}{l}\text { Improved control systems and } \\
\text { Thyristor drives, sequential } \\
\text { operation, efficient } \\
\text { transportation (efficient } \\
\text { pumping etc.) }\end{array}$ & $\begin{array}{l}\text { Contributes to reduction } \\
\text { of about } 60-100 \mathrm{kWh} / \mathrm{t} \\
\text { alumina }\end{array}$ \\
\hline
\end{tabular}




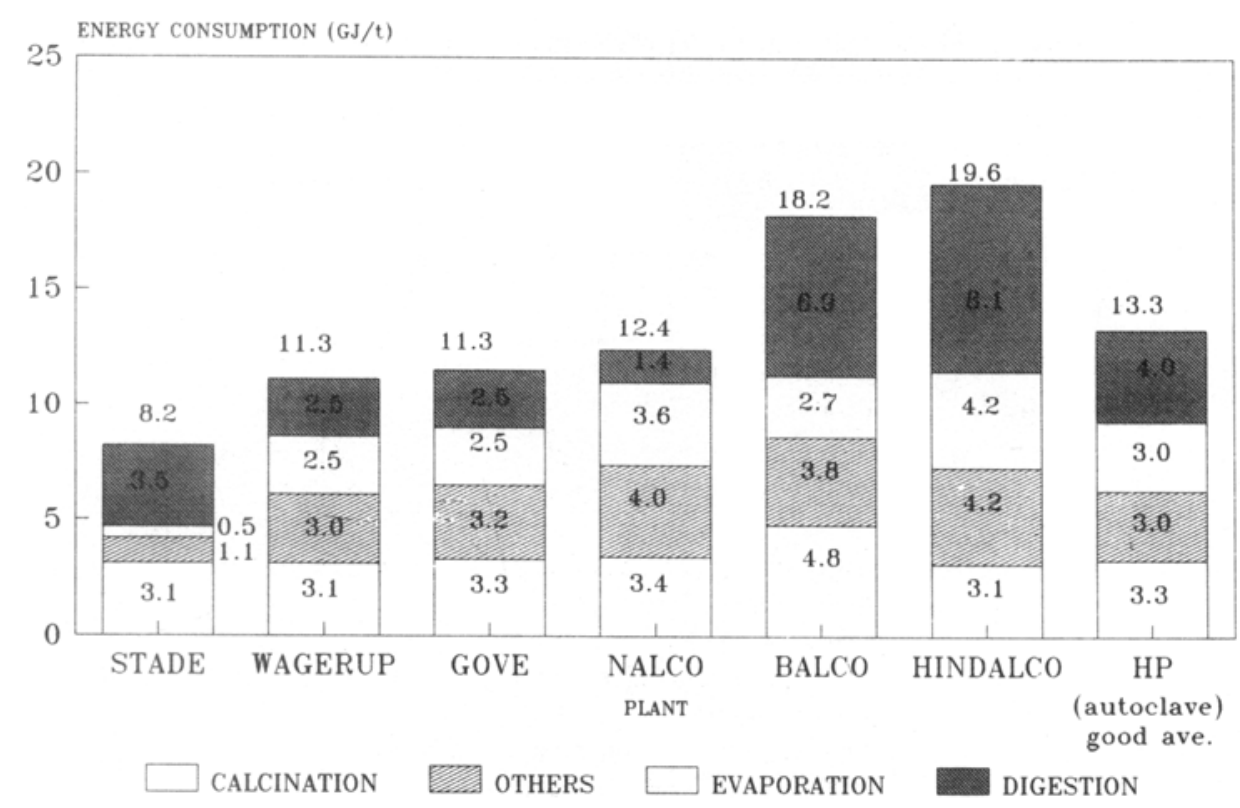

Figure 6. Heat energy consumption of different alumina plants.

The Indian alumina refineries, with the exception of NALCO, employ technologies which are outdated, because of which the liquor productivity of the Indian plants is considerably lower than those achieved in modern plants. For example, the Gove plant in Australia has a liquor productivity of about $85 \mathrm{~kg} / \mathrm{m}^{3}$ in contrast to $55-70 \mathrm{~kg} / \mathrm{m}^{3}$ achieved in the Indian alumina plants. The fineness of the product varies with NALCO and HINDALCO producing alumina of $5-10 \%,-45 \mu \mathrm{m}$ fraction whereas BALCO produces alumina of $35-40 \%,-45 \mu \mathrm{m}$ fraction. The present situation in the Indian alumina plants and the future targets for improvement are schematically illustrated in figure 5 (Light Metals Age 1994).

The performance of the Indian plants also needs considerable improvement from the point of view of energy consumption. Data pertaining to energy consumption of various alumina plants in the world are shown in figure 6 (Bitsch 1991; Aluminium Verlag 1994) from which it is clear that the Indian plants consume about 50 to $125 \%$ more energy than the best plant (Stade, Germany) in the world. Considering the high cost of energy in India, it is imperative that immediate actions are taken to minimize energy consumption in the Indian plants.

The average cost of production of alumina in the world plants is about US\$200/t. In spite of a combination of unfavourable factors - higher consumption of energy, lower liquor productivity and lower scale of operation-the production cost of alumina in NALCO is the lowest in the world (figure 7) (King 1993).

The production cost in other plants are also on the lower side compared to the world average, mainly due to favourable factors related to bauxite cost and labour. The consumption of all other raw materials and energy and their unit costs are on the higher side. Consequently, there is considerable scope for improvement. The cost of production in all alumina plants (even those with capacities of $1-1.5$ million) is found to be more than US \$ 175 except for the Pinjara (Australia) plant. Bauxite and capital costs in 


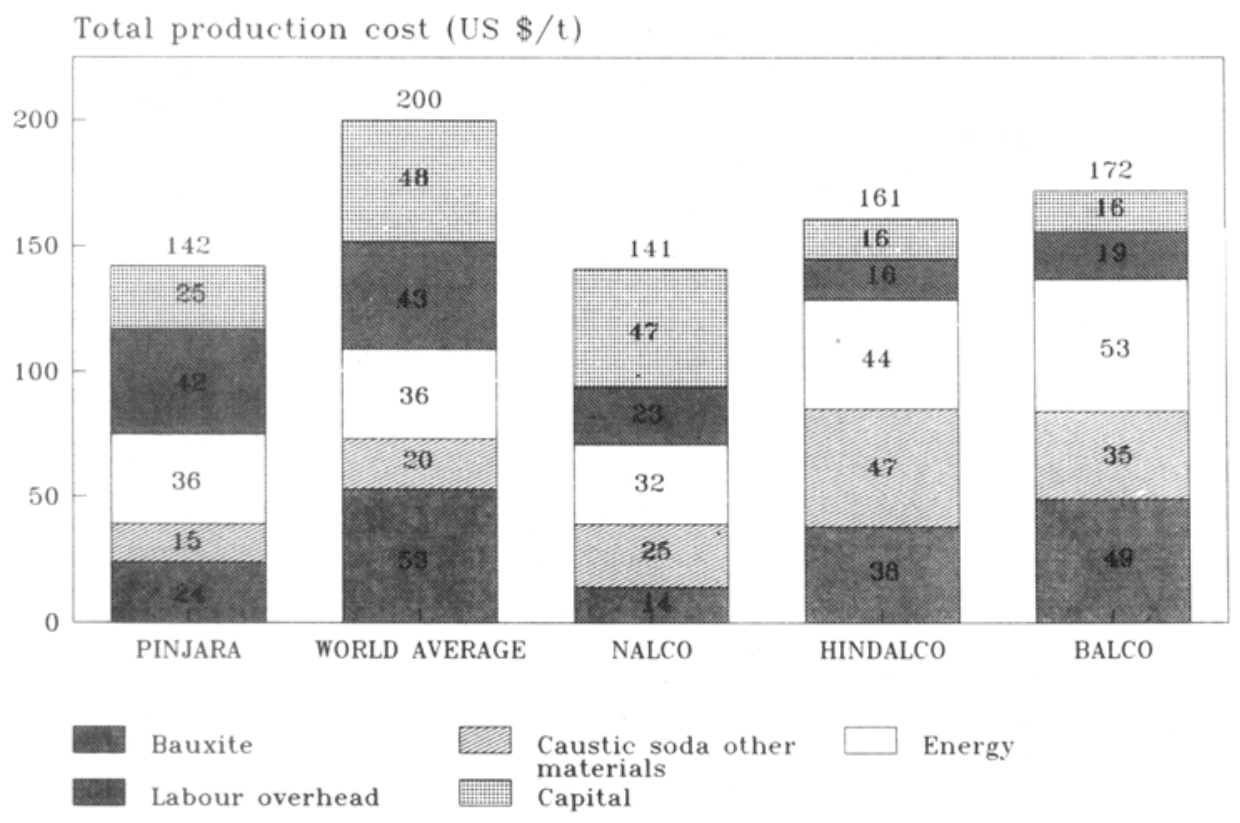

Figure 7. Competitiveness of Indian alumina refineries.

such plants account for $50-60 \%$ of the production cost. It may be noted that the capital cost requirements for various options of increasing the production capacity are as follows:

$\begin{array}{ll}\text { Intensification of the process } & \$ 100 / \mathrm{t} \\ \text { Brown field expansion } & \$ 500-600 / \mathrm{t} \\ \text { Green field project } & \$ 1000-1200 / \mathrm{t}\end{array}$

It is clear that wherever possible it would be appropriate to intensify the process and enhance the capacity. This implies that the component of capital cost in the total cost for production would be only about $\$ 8-10$ as against $\$ 50-60$ for brown field expansion and \$100-125 for green field plants. Because of the high grades ores available in this country, especially in the eastern coast and in close proximity to large ports, it has been estimated that even green field plants could be established with production costs of US $\$ 160-175 / \mathrm{t}$.

\section{Aluminium production}

The Hall-Heroult process for the production of aluminium has been under exploitation for well over a century; while competing processes such as carbothermic reduction of alumina and electrolysis of aluminium chloride have been considered (Gardner et al 1981), no breakthrough has been achieved. On the other hand, substantial improvements in the size of the Hall-Heroult cells, current efficiency of the electrolysis process, metal purity, power consumption and material savings have been achieved by concentrated research and development activities. These are illustrated with a set of data for 
Table 4. Advances in prebaked smelter technology.

\begin{tabular}{|c|c|c|c|}
\hline Parameters & $1955-65$ & 1980’s & $\begin{array}{l}\text { Best Indian } \\
\text { value }\end{array}$ \\
\hline Cell type* & CWPB \& SWPB & PFPB & PFPB \\
\hline Cell size $(\mathrm{kA})$ & $80-140$ & $\begin{array}{l}175-300 \text { (a } 350 \mathrm{kA} \\
\text { cell is reported to } \\
\text { be under } \\
\text { development) }\end{array}$ & 180 \\
\hline $\begin{array}{l}\text { Power consumption } \\
\text { (DCkWh/kg) }\end{array}$ & $15 \cdot 2-17 \cdot 0$ & $12 \cdot 9-13 \cdot 2$ & 140 \\
\hline $\begin{array}{l}\text { Man hours/tonne of } \\
\text { metal }\end{array}$ & $10-15$ & $3 \cdot 5-5 \cdot 8$ & \\
\hline $\begin{array}{l}\text { Net carbon } \\
\text { consumption }(\mathrm{kg} / \mathrm{kg} \\
\text { of metal) }\end{array}$ & $0.46-0.49$ & $0.40-0.43$ & 0.42 \\
\hline Cell life (months) & $25-30$ & $65-100$ & \\
\hline $\begin{array}{l}\text { Metal purity } \\
\text { achievable }\end{array}$ & $99 \cdot 8$ & 99.97 & 99.85 \\
\hline
\end{tabular}

*CWPB, Centre-worked prebaked; SWPB, side-worked prebaked; PFPB, point-fed prebaked

the advances in the prebaked electrode technology over three decades in table 4 (Welch 1989). Also included in the table are the best performance data of the Indian smelters. These advances have been made possible as a result of our better understanding of the chemistry of electrolysis, the factors which contribute to the deterioration of the electrodes and the application of the knowledge/experience gained to improve the engineering design and production of electrodes. Some important considerations in this regard are the following:

- Properties of the electrolytic bath as influenced by additions of other salts

- Better control of alumina concentration in the bath by controlled feeding

- Detailed analysis of heat, voltage and magnetic field distribution in and around the cell

- Development of materials (particularly for electrodes) for better corrosion resistance and thermal and electrical conductivities

- Greater emphasis on pollution control

These factors are briefly discussed below.

\subsection{Bath chemistry}

The effect of additions of a variety of compounds to cryolite has been studied in detail and the following factors are to be considered in this regard:

- Density of electrolyte should not exceed $2100 \mathrm{~kg} / \mathrm{m}^{3}$ to ensure a good separation between the bath and the metal layers

- Good electrical conductivity to ensure lower cell voltage and therefore reduced power consumption 
- Reduced solubility of aluminium in the bath to minimize oxidation of aluminium by carbon dioxide thereby leading to better current efficiency

- Better chemical stability of the additivities to ensure metal purity

- Additives should not lead to acceleration of corrosion reactions and not contribute to extra pollution problems

- Ensure that the solubility of alumina is adequate enough to minimize the possibilities of formation of sludge or muck which would introduce cell instabilities.

Detailed information on the effects of additions of a variety of salts $\left(\mathrm{CaF}_{2}, \mathrm{AlF}_{3}, \mathrm{LiF}\right.$, $\mathrm{MgF}_{2}, \mathrm{NaCl}$ etc) to the electrolyte on alumina solubility, electrical conductivity, density, viscosity, liquidus temperature, metal solubility, surface tension and vapour pressure is available in the literature (Burkin 1985). Practically possible additions are $\mathrm{CaF}_{2}, \mathrm{AlF}_{3}, \mathrm{MgF}_{2}$ and $\mathrm{LiF}$. Since most of the additivities reduce alumina solubility, and a reduction of melting point of the bath by about $50^{\circ} \mathrm{C}$ would typically halve the solubility of alumina, bath additions can be effective only with good process control and alumina feeding technologies.

\subsection{Alumina feeding and process control}

It is now well-established that the optimum concentration of alumina in the bath is $\sim 2 \%$. Controlled alumina feeding is commercially realized by localized charging of small amounts of alumina at regular intervals. The old techniques of breaking the side crust and feeding alumina once in 4 to $8 \mathrm{~h}$ (which invariably leads to large variations in alumina concentration in the bath) is replaced by mechanical crust breaking and feeding systems. The major breakthrough is the alumina point feeding system which involves the breaking of the crust by single piercing rods at 2 to 5 positions along the central axis of the cell and introducing $0.5-3.0 \mathrm{~kg}$ of alumina (volumetrically measured) every 30 to $60 \mathrm{sec}$. This technological innovation has led to considerable improvement with regard to incidence of anode effects, 0.1 per day in present day cells compared to about 3 per day in cells of older design. The development of point feeding system for Soderberg cell has been mentioned (Jarrett 1987) in the literature.

\subsection{Mathematical modelling}

It is clear that productivity of the cell can be improved considerably by increasing the size and amperage. However, this introduces problems with regard to compensating the distorting and stirring effects on the metal pad in the cell. Mathematical modelling of magnetic field has contributed to design variations which flatten the contour of the metal pad and reduce circulating velocities. The latter imply less chances for reoxidation of aluminium - in fact magnetic field compensation is responsible for breakthrough in current efficiency exceeding $92 \%$. Modelling of thermal energy distribution is a more formidable problem particularly during anode changes, metal tapping and alumina feeding. Currently developed mathematical models integrate magnetic, thermal and electrical effects and also take process dynamics into account. Many of these aspects have been reviewed in a Workshop organized by the Jawaharlal Nehru Aluminium Research Development and Design Centre in Nagpur in 1993 (Charette et al 19931 . 
Table 5. Properties of electrode materials and their influence on cell operation.

\begin{tabular}{|c|c|c|}
\hline Property & Typical value & $\begin{array}{l}\text { Influenced cell } \\
\text { parameter }\end{array}$ \\
\hline $\begin{array}{l}\text { Specific electrical } \\
\text { resistivity }\end{array}$ & $50-60 \mu \Omega \mathrm{m}$ & Energy consumption \\
\hline Apparent density & $1.50-1.60 \mathrm{~g} / \mathrm{cm}^{3}$ & Net carbon consumption \\
\hline Air permeability & $0.5-2.0 \mathrm{nPm}$ & \\
\hline $\mathrm{CO}_{2}$ reactivity & $\begin{array}{l}\text { Residue } 84-96 \% \\
\text { dust } 1-10 \% \text {; loss } 4-10 \%\end{array}$ & \\
\hline Air reactivity & $\begin{array}{l}\text { Residue } 65-90 \% \text {; dust } \\
2-10 \% \text {; loss } 8-30 \%\end{array}$ & \\
\hline Silicon & $100-300 \mathrm{ppm}$ & \\
\hline $\begin{array}{l}\text { Thermal expansion } \\
\text { coefficient }\left(20-30^{\circ} \mathrm{C}\right) \\
\text { Thermal conductivity } \\
\text { Fracture energy }\end{array}$ & $\begin{array}{l}3.7-4.5 \times 10^{-6} / \mathrm{K} \\
3.0-4.5 \mathrm{~W} / \mathrm{mK} \\
250-350 \mathrm{~J} / \mathrm{m}^{2}\end{array}$ & Thermal shock \\
\hline $\begin{array}{l}\text { Sulphur } \\
\text { Vanadium } \\
\text { Nickel } \\
\text { Iron } \\
\text { Sodium }\end{array}$ & $\begin{array}{l}1 \cdot 5-2-5 \% \\
80-260 \mathrm{ppm} \\
80-160 \mathrm{ppm} \\
100-500 \mathrm{ppm} \\
400-1000 \mathrm{ppm}\end{array}$ & Metal contamination \\
\hline
\end{tabular}

\subsection{Electrode materiais}

As a result of extensive studies, a wealth of information on the requirements of raw materials used in the manufacture of electrodes and the influence of various properties of the end products on smeiting parameters has been collected. Some details in this regard are summarized in table 5 (Mannweiler 1994).

Continuous improvements to anode technology have now brought the anode consumption to $\sim 400 \mathrm{~kg} / \mathrm{t}$ of metal as against the theoretical value of $333 \mathrm{~kg} / \mathrm{t}$. The use of inert materials as anodes has been extensively discussed in literature but a breakthrough is still to be made.

The life of the cell and current efficiency can be increased by protecting the cathode surface against attack by cryolite, and against penetration by sodium. Recent studies on the application of a slurry of $\mathrm{TiB}_{2}$ as a thin coating to the cathode have indicated improvements in cell parameters, particularly in energy and current efficiencies. The TINOR coating developed by MOLTECH Switzerland for this purpose is presently under investigation in some plants and the results are likely to be encouraging (deNora 1994).

\section{Pollution control}

Important waste materials generated during production of alumina and aluminium are the following:

- Red mud, the residue of the bauxite digestion treatment

- Fluoride emissions resulting from the vaporization of some of the constituents of the electrolytic bath 
- Spent pot lining - the waste cathode material

- Particulate

- Polycyclic aromatic hydrocarbons (PAH's)

- Sulphur dioxide

Some important characteristics of these constituents and methods of disposal are discussed in the following paragraphs.

\subsection{Red mud}

About 1.5-2 t of red mud is generated for every tonne of alumina produced; considering that the present world annual production of alumina is about 40 million tonnes, it is clear that an enormous amount of red mud is produced. Typically red mud contains $\sim 4 \mathrm{~g}$ of sodium hydroxide per litre and therefore presents considerable problems in disposal. The methods developed for disposal along with their merits and demerits are summarized in table 6 . Furthermore, the mud also contains degradable organics, which when returned to the system caused unnecessary problems. The economical utilization of red mud has been a subject of considerable discussion throughout the world (UNEP 1985) and the storage of such large quantities of material ( 5 million tonnes of slurry is generated in a 1 million tonne plant)

Table 6. Merits and demerits of various methods of disposal of red mud.

\begin{tabular}{|c|c|c|}
\hline Method & Merits & Demerits \\
\hline Slurry disposal & $\begin{array}{l}\text { Return of caustic to plant; } \\
\text { cheaper mode of transport; } \\
\text { low infrastructure investment; } \\
\text { natural surfaces can be used } \\
\text { for providing banks }\end{array}$ & $\begin{array}{l}\text { Large space requirements; } \\
\text { higher storage cost; high } \\
\text { investment for building ponds; } \\
\text { potential pollution hazards; } \\
\text { continuous need for } \\
\text { enlargement of ponds or } \\
\text { erection of new ponds; } \\
\text { reclamation of area is } \\
\text { expensive and time consuming }\end{array}$ \\
\hline Dry mud disposal & $\begin{array}{l}\text { Environmentally preferred; } \\
\text { requires less space; } \\
\text { consolidates rapidly }\end{array}$ & $\begin{array}{l}\text { High investment costs on } \\
\text { machinery for concentrating } \\
\text { the slurry and pumping; higher } \\
\text { energy and expensive earth } \\
\text { moving equipment }\end{array}$ \\
\hline Sea/lake disposal & $\begin{array}{l}\text { No investment on ponds; } \\
\text { moderate investment on } \\
\text { machinery for transportation; } \\
\text { lower energy requirements }\end{array}$ & $\begin{array}{l}\text { No return water and hence less } \\
\text { recovery of caustic; harmful to } \\
\text { marine organisms in the long } \\
\text { run; should be dumped at } \\
\text { depths exceeding } 3000 \mathrm{~m} \text {; } \\
\text { extensive pipe line } \\
\text { requirements }\end{array}$ \\
\hline Solar drying & $\begin{array}{l}\text { Area required is less than } \\
\text { that for slurry disposal but } \\
\text { more than that for dry } \\
\text { disposal; reduced soluble } \\
\text { soda losses }\end{array}$ & $\begin{array}{l}\text { Requires stand-by method for } \\
\text { use during rainy seasons; large } \\
\text { requirements of even surfaces; } \\
\text { need for pumping rain water }\end{array}$ \\
\hline
\end{tabular}


poses a continuous environmental problem to the habitat in and around the storage ponds. From the point of view of red mud utilization, the processes can be grouped as follows:

- Processes utilizing red mud completely

- Processes utilizing certain constituents of red mud

- Processes utilizing red mud as an alumina plant end product.

A short list of the various processes found technically viable are (Aluterv 1980):

- Production of molten iron, alumina and cement

- Reductive smelting of red mud

- Utilization of red mud for cement production

- Utilization as building and construction material

- Utilization for soil amelioration and road building

- Utilization of mud slurry to neutralize $\mathrm{SO}_{2}$

- Red mud plastic

- Bricks and tiles manufacture

In India but for manufacturing of red mud plastics, no other method is in commercial use. Even in the developed countries at present the mud is being mostly stored in dykes as no techno-economically viable solution for the utilization has been made.

\subsection{Fluoride emissions}

Fluoride emissions are expressed as $F_{\mathrm{g}}$ for gaseous fluorides, $F_{\mathrm{p}}$ for particulate fluorides entrained in the gas streams and $F_{\mathrm{t}}\left(=F_{\mathrm{g}}+F_{\mathrm{p}}\right)$ for total fluorides. Fluoride emissions result mainly from the electrolysis cells, but some amounts are also released from the anode baking ovens. The total can be typically in the range $20-40 \mathrm{~kg} / \mathrm{t}$ of Al depending on the cell operating temperature, electrolyte composition, cell hooding arrangements, volume and humidity of ambient air leakage to the cell and method of crust breaking and alumina feeding. Bag filters are extensively used for dry scrubbing in which the removal of hydrogen fluorides in the fumes is achieved by chemical absorption using alumina feed stock (Singmaster and Brayer 1973; IPAI 1978). Even a contact time of the order of a few seconds is sufficient to give rise to removal efficiency of $99 \%$. The alumina requirements are sandy variety with a specific surface area of at least $25 \mathrm{~m}^{2} / \mathrm{g}$.

\subsection{Spent pot lining}

About one million tonne of spent spot lining are generated annually by the world aluminium industry. This material contains significant amounts of carbon $(\sim 40 \%)$, fluoride $(\sim 15 \%)$, sodium $(\sim 15 \%)$. The most deleterious impurity is cyanide with concentrations in the range $0 \cdot 1-0 \cdot 3 \%$ : occasionally higher values are reported. Treatment of spent pot lining for the recovery of the valuable fluoride constituents can be achieved by one of the following methods (Pawleck 1993):

- low temperature leaching

- gas treatment (moderate temperature)

- thermal treatment (high temperature) 
There is some information in the literature about the use of spent pot lining in the manufacture of iron and steel (Ianka 1994).

\section{Conclusions}

A critical analysis of the developments that have taken place in last five decades in the alumina and aluminium industries leads to the following conclusions:

innovative technology and improvements in equipment design have improved process efficiency and productivity

there is a significant increase in scale of operation leading to reduction in fixed and semi-variable costs of production

capacity to process different grades of bauxite in the same alumina plant has been developed

significant improvements in current efficiency and reduction in power consumption have been achieved in the electrolysis of alumina

disposal of solid wastes has been carried out in a more efficient manner leading to more than $60 \%$ savings in space for storage of the waste

environmental pollution problems arising from alumina calcination and aluminium smelting have been tackled efficiently

while the performance of the Indian plants have improved significantly in the last two decades, lower scale of operation and higher cost of some of the raw materials, in general, lead to higher direct costs of production

$\mathrm{R}$ and $\mathrm{D}$ activities in the field of alumina/aluminium are to be accelerated in the country so as to exploit economically the vast bauxite resources available in the country

\section{References}

Alumina refineries and producers of the world 1994 Aluminium Verlag GmbH-Dusseldorf-Germany Aluterv F K I 1980 Report on study on the disposal and utilization of bauxite residues, Budapest, Hungary Bielfeldt $\mathrm{K}$ and Winkhaus G 1981 Proc. int symp. of ICSOBA, Thany. Hungary p. 111

Bitsch R 1991 INCAL-91 proceedings (Bangalore: Aluminium Association of India) Vol. I, p. 93

Burkin A R 1985 Critical reports on applied chemistry (J. Wiley and Sons) Vol. 2

Charette A, Peter S. Potocnik V and Tikasz L 1993 Workshop proceedings on mathematical modelling of aluminium production technology (Nagpur: Jawaharlal Nehru Aluminium Research Development and Design Centre)

Dixon P H and Schunk H J 1993 Third int. alumina quality workshop, Hunter Valley, Australia p. 12

Doucet J 1993 Third int. alumina quality worshop. Hunter Valley, Australia p.93

Feik $\mathrm{H} J$ and Cordes $\mathrm{H} 1971$ Second int. symp. of ICSOBA, Hungary Vol.3, p. 1

Gardner H J. Grojotheim K and Welch B J 1981 Proc. of ICSOBA symp., Tihany, Hungary. p. 27

Ianka E A 1994 Private communication

IPAI 1978 Monitoring of emissions from primary reduction plants (London: International Primary Aluminium Institute)

Jarrett N 1987 Production of alumina and aluminium (ed.) A R Burkin (Chinchester, UK: John Wiley and Sons) p. 188

King J 1993 Aluminium cost report, GSC analysis, statistics

Lang G, Solymar K and Steiner J 1981 Light Metals p. 201

Light Metal Age 1994 A review of smelters in India. Gulf. Arab regions and Turkey pp 40-53 
Mannweiler V 1994 Support of India's aluminium industry in the field of anode technology (Switzerland: R \& D Carbon Ltd.) p. 10

Newchurch F N and Moretto K E 1990 Second int alumina quality workshop, Perth, Australia p. 1 de Nora V 1994 Aluminium 70546

Pawleck R P 1993 J. Metals 4548

Plunkert P A 1993 Application of Alcan's deed thickener technology for thickening and classification. American Filtration Society Annual Meeting, Chicago

Singmaster D and Brayer J P 1973 Air pollution control in the primary aluminium industry, prepared for Environmental Pollution Agency, USA

Welch B J 1989 Metals Mater. Process. 137

UNEP 1995 Environmental aspects of alumina production-A technical review, Paris 